\title{
Rendang lokan: history, symbol of cultural identity, and food adaptation of Minangkabau tribe in West Sumatra, Indonesia
}

\author{
Siti Fatimah ${ }^{1 *}$, Delmira Syafrini ${ }^{2}$, Wasino ${ }^{3}$ and Rahadian Zainul ${ }^{4}$
}

\begin{abstract}
Rendang is a kind of food that has become one of cultural heritages of Minangkabau tribe. It is not only a local food that has been crowned the best food in the world by CNN, but it also serves as the cultural identity. Most of people think that rendang is only made from beef of buffalo meat. In fact, rendang has many varieties that relate to the types of the area and the local natural resources where it is cooked. West Sumatra consists of mountainous and coastal areas. One of the popular rendang varieties in coastal areas is Rendang Lokan -it is not made from beef but oyster (lokan). Rendang Lokan is a kind of food for people who live in this area. They use resources of the sea for their foods. Rendang, for Minangkabau tribe, is not only considered as a traditional food but also as a symbol of cultural identity from a certain area. This article is aimed at discussing the history of using Oyster as the main ingredient for rendang as one of the rendang varieties coming from the coastal areas in West Sumatra. The results show that rendang lokan is a representation of the characteristics of Minangkabau people who have the ability to adapt themselves to the local environmental conditions in maintaining their cultural identity. Rendang lokan was initially created as the adjustment of the Minangkabau people who live in the coastal areas to the local natural resources and their economic conditions.
\end{abstract}

Keywords: Rendang lokan (oyster), History of rendang, Cultural identity, The adaptation of food of Minangkabau tribe

\section{Introduction}

Today, food does not simply fulfil people's daily need and appetite, but it also shows the identity of certain community [1]. Every region has specific food which shows the heritage and pride of its people from generation to generation $[2,3]$. This also applies in all tribes throughout Indonesia. Indonesia is a multicultural country composed of 633 tribes [4]. Each tribe has specific food as its cultural identity [5]. One of the best and popular foods in Indonesia is rendang. The food is

\footnotetext{
* Correspondence: sitifatimah@fis.unp.ac.id

'Department of History, Faculty of Social Sciences, Universitas Negeri Padang, West Sumatra, Indonesia

Full list of author information is available at the end of the article
}

originally from Minangkabau tribe who lives in the province of West Sumatra, often called Minangkabau world. Rendang from Minangkabau has already been declared as one of the 50 delicious foods in the world with number 1 at voting based on the version of CNN [6].

Recently, for at least 10 years, the study of rendang has attracted the attention of scholars to analyze it from various perspectives such as its nutrition [7], its cooking process and quality [8], and its status as the traditional food [9]. The other research is about its origin from historical perspectives [10]. The research about rendang as the cultural identity of the society however is still limited. Most of the previous studies focused on rendang as the culinary of Minangkabau society with the meat as its

(c) The Author(s). 2021 Open Access This article is licensed under a Creative Commons Attribution 4.0 International License, which permits use, sharing, adaptation, distribution and reproduction in any medium or format, as long as you give appropriate credit to the original author(s) and the source, provide a link to the Creative Commons licence, and indicate if changes were made. The images or other third party material in this article are included in the article's Creative Commons licence, unless indicated otherwise in a credit line to the material. If material is not included in the article's Creative Commons licence and your intended use is not permitted by statutory regulation or exceeds the permitted use, you will need to obtain permission directly from the copyright holder. To view a copy of this licence, visit http://creativecommons.org/licenses/by/4.0/. 
main ingredient, not oyster. In fact, rendang has many varieties that relate to the types of the region and the resource of nature where local people live in the province of West Sumatra.

The variation of rendang reflects the ability of the local people to face their life challenges, explore their local wisdom, and adapt themselves to the surrounding environment and available natural resources. The people who live in the mountainous areas have the ability to cook rendang with meats, chickens, eggs, or even eels as the main ingredients, while the people who live in the coastal areas have the ability to cook rendang with the natural resources available in the sea, such as fishes and oysters, as the main ingredients. This shows their cultural identity and ability to adapt to the local environmental condition in order to fulfil their daily needs. Rendang has become prestigious and popular culinary in Indonesia. The variation of rendang proves that Minangkabau people are able to adapt themselves to their local environmental condition [11].

Rendang lokan is very popular in West Sumatra showing the characteristics of people who live in the western coastal areas. The oysters which live in the west coasts of West Sumatra are different from those living in other places. The people in this area call them Lokan. In addition to showing a specific food from this area, using lokan as the main ingredient of rendang shows the local people's creativity in processing food for their needs. Rendang lokan is very delicious and certainly has different taste from rendang made from beef or buffalo meat. Moreover, that the price of oyster is cheaper than beef or other kinds of meat triggers the local people to be more creative in producing rendang lokan as an identity of culinary. In addition to the taste and price aspects, lokan is a food that is in high demand because of its excellent nutritional content. The nutritional content contained in the main ingredient, such as in lokan, is an important factor to be considered in processing traditional food [12], because food is not only to meet the needs of life but also to support health as an indicator of welfare of human life. The complete composition of lokan, including its taste, price, and nutritional content, makes this kind of rendang in high demand by people in West Sumatra. Rendang lokan used to be a culinary tradition of people living in coastal areas which was usually served at traditional parties, especially at weddings. Nevertheless, recently, the food has gained its popularity and is now available in some restaurants and the food stores as the souvenir.

This article is aimed at discussing the history of rendang lokan as the Minangkabau people's traditional food, representative of their cultural identity and their ability to adapt to their local environmental condition. This topic is interesting to study since it provides new knowledge about the variation of rendang. Besides, it offers new ways to analyze traditional food in terms of anthropological, sociological, and historical perspectives. Thus, it triggers comprehensive knowledge about food as a cultural identity, fulfilment of people's daily needs as well as ways to survive. The previous article about rendang lokan simply discussed it as the culinary tour [13]. However, it did not investigate the ingredients, process of cooking, and background history of rendang lokan as the variety of rendang initiated by the people who live in a western coastal areas of West Sumatra. This article, therefore, offers the originality of value and the newest study about local food of the tribe both as an identity and ability of the local people to be innovative in adapting to the local available resources.

Food is the characteristics of a certain society as well as a kind of cultural identity [14]. A cultural identity refers to cultural egalitarian held by a group of people who are from the same ancestor and history and make them as a community [15]. The identity involves learning and accepting the tradition, heritage, language, religion, ethic, mindset, and socio-cultural values found in the community as the concept of their lives [16]. This identity is a signifier for the same or different socio-cultural background between one community and others, which make them proud of it [17]. Thus, rendang is a kind of cultural identity of Minangkabau people as well as their pride wherever they are [18].

\section{Research method}

The research used a qualitative method by collecting data through participation observation, interview, and analysis of secondary data. The method is used to reveal how the society considers the food as their cultural heritage and identity. In the perspectives of sociology and anthropology study, the food is considered as an expression of the society its self that makes them different from others [2]. It makes them proud and have honor to be a part of Minangkabau tribe. Thus, the way they consider the food as heritage and identity relates to knowledge, awareness, and subjective meaning that they have both as an individual and the member of the Minangkabau tribe. As a result, it is difficult to reveal the meaning and experience of the actor by using category and rules of qualitative research. Based on the problem that has been formulated, this research used observation and interview to highlight the process, meaning, definition of situation, and experience as the basis of their actions in their social life. This is in line with ethnography approach in cultural research [19].

The observation was done in several places, including in the houses of the people who cooked rendang for wedding parties or other celebrations, at restaurants which served rendang as one of their menus, food stores, 
and the center of souvenir for special Minangkabau's food, especially in Pesisir Selatan Regency of West Sumatra Province. The observation was done to see the process of cooking rendang step by step. Through the observation on the ingredients, tools and the process of cooking rending, it was found that the philosophy of rendang was realized through the way it is cooked. The interview was done in detail to 20 informants as the representative of the society from high land and coastal areas. The purposive sampling technique was used to decide the informants based on the criteria and the aim of the research. The criteria for informants were (i) $\mathrm{Mi}$ nangkabau people who live in West Sumatra; (ii) having the ability to cook rendang; and (iii) leader of women called Bundo Kanduang (mother). The interview was done around 3 to $90 \mathrm{~min}$ to know more about the philosophy and history of rendang, kind of rendang based on the characteristics of area, the ingredients, and the process of cooking as well as the meaning of it for the Minangkabau society. Then, the result of the interview was transcribed, categorized, and compared to the observation and secondary data. Then, they were analyzed by using the relevant theory. The research was supported by oral history and oral tradition by collecting the information directly from the people who knew the historical tradition of cooking rendang. They were also the actors in expressing their experiences. It can be revealed that rendang lokan is the food created by the adaptation of society in coastal area to the condition of their local environmental conditions [20].

The data were analyzed using an interactive analysis model whose stages included data reduction, data display/presentation, verification, and conclusion (Fig. 1). In the first stage, the collected data were processed through data selection, coding, and simplification. Afterwards, the data were arranged into a collection of categorized and synthesized information, then the data were presented in the form of narration supported by pictures, tables, and charts. Based on the process of data

Process of data collection and analysis

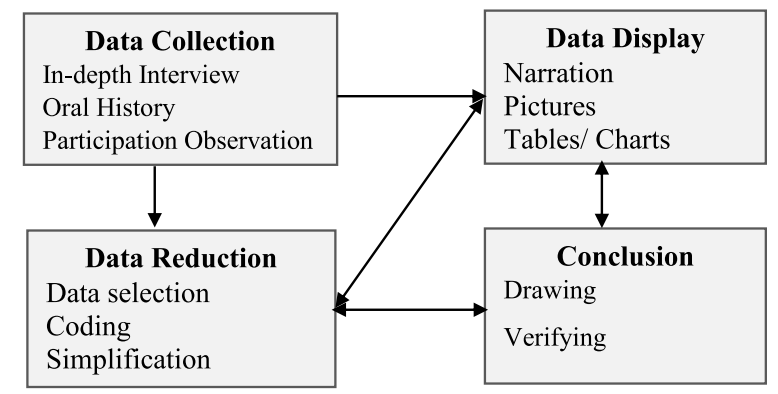

Fig. 1 Process of data collection and analysis reduction and presentation, the data were then verified and conclusions were drawn, involving the interpretations of the authors regarding the data presented [21]. By combining the techniques to collect the data, the results of the research were valid about the variation of rendang based on the geographical characteristics of the area and the representation of identity Minangkabau society.

\section{Results and discussion}

History of rendang lokan

There is no exact source informing when the first rendang lokan is found since it is not a tangible cultural heritage. It is closely related to an intangible cultural heritage, thus it is the cultural process which is called immaterial in which the process is evolution. The history of rendang lokan is related closely to the mobility of the society from high land to the coastal area. For Minangkabau society, culinary of rendang is the manifestation of cultural mobility. In the Minangkabau custom, people who want to go somewhere out of their hometown are usually provided with rendang [22], and this has been implemented since a long time ago, especially since Islam came into Minangkabau. The familiar myth in Minangkabau society especially for women is "they are not Minangkabau if they do not know how to cook rendang."

As a matter of fact, the process of cooking rendang has been known since the bronze culture called blacksmiths culture (budaya pandai besi). It is impossible to cook rendang without using a large deep frying pan (kuali basi). The process is derived from the place in a high land area which is called main land (Luhak nan tigo or daerah darek). In line with the process of mobility in the past, since the entrance of Islam and the colonial times, rendang has developed through some innovations in its materials and ingredients, based on the situation and environment. This is suitable with the characteristics of the Minangkabau people who are called Egalitarian because they are able to adapt to the new World.

The existence of rendang lokan is the result of the mobility process and ability of Minangkabau people in adapting to the environment where they live. This creates several innovations including culinary in accordance with the egalitarian characters of Minangkabau people. The first destination they headed was the coastal areas, then they might continue to another place on the other island. In the coastal areas, they built a new settlement with the new model of the traditional house (Rumah Gadang) where its architecture was different from their original one. They are however sure that they still have relationship with their village indicated by their way of living, i.e., they still live together with their own clan [23]. It shows that Minangkabau has settled in coastal 
areas in which they develop and keep the identity of their clan such as Body, Caniago, Melayu, Koto, and Pitupang.

Then, they try to adapt to the natural resources around them. They manage the resources with their own knowledge they had from their original village, high land. One of them is culinary of rendang. They also have variety of local knowledge such as farming, architecture of building, art, literature, herbal medicine, and culinary. Rendang lokan is the manifestation of Minangkabau society in adapting to their environment, as well as the combination of local wisdom they own.

Today rendang lokan is available in Pesisir Selatan Regency, such as in the center of rendang and restaurant. It is different from the high land, where the restaurants do not have it. In line with the development of the tourist resort, the coastal areas become more popular so that rendang lokan is the favorite culinary for both local and foreign tourists who visit the area. Nearly every restaurant in the area put on the banner or brand with the information that rendang lokan and curry of reef fish (gulai ikan karang) are available. Both of these culinary are the icon of the Minangkabau society in coastal areas.

\section{Rendang lokan: specific culinary of people living in coastal areas of West Sumatra.}

Rendang, as the specific culinary of Minangkabau people, now becomes the main menu and favorite food which is familiar in Indonesia. Besides, along with the development of tourism in Pesisir Selatan Regency, rendang lokan has been popular in foreign countries. The society outside Minangkabau, however, only knows one kind of rendang that is rendang with meat. In fact, there are many kinds of rendang based on the local natural resources. People who live in the highland use any kind of cattle or vegetables grown up in their area to cook rendang. But the people who live in the low land or coastal area use the resources of the sea to cook rendang with any ingredients from the nature around them. The difference of the sources creates the specific taste from each of rendang even though the process and the way how to cook are mostly the same.

Rendang lokan is one of the popular foods in West Sumatra. It is a kind of rendang with oyster that reflects the character of Minangkabau people who live along the coastal areas in West Sumatra, especially in Pesisir Selatan Regency (Fig. 2). It is their icon and pride of the coastal area since it is the main resource in their environment which cannot be found in the mountainous are.

Oyster is a kind of Geloina Erosa that live in mangrove area, in a bottom of water, since its habitat is in a mud area (Fig. 3). It becomes foodstuffs and source of animal protein for Minangkabau people living in the coastal areas West Sumatra. It has a high nutritional content, consisting of $7.06-16.87 \%$ protein composition, 0.40 $2.47 \%$ fat, $2.36-4.95 \%$ carbohydrate and energy with 69 88 calcium/100 g [24].

Besides, oyster is easy to get and its price is so cheap that the society tends to choose it as the main ingredient to cook rendang. Today, the price of meat is more expensive, around IDR $120.000 / \mathrm{kg}$ while the oyster is only IDR $75.000 / \mathrm{kg}$. The reasons mentioned above make rendang lokan one of alternative foods in West Sumatra, especially for the society along the coastal areas who are commonly fishermen. When they cannot afford to buy meat, they still get nutrition from oyster and cook it as rendang.

Rendang lokan is also famous because of its distinctive taste. Cooking rending requires fresh oysters with some other ingredients which grow in their area. They are coconut milk, ginger, turmeric, lemon grass, and other ingredients from plantation around their house. All the materials are processed by hand (manual) not machine. Coconut milk is squeezed out of coconut and other ingredients are ground by the grinding stone (Fig. 4). They believe the taste is different if it is hand-made rather than using a machine (technology).

All the ingredients for rendang lokan are the same as rendang with meat. One kilogram of oyster requires 300 $\mathrm{g}$ of finely ground chilli, $4 \mathrm{~L}$ of coconut milk (out of 4 coconuts), 15 cloves of finely ground onion, 5 cloves of finely ground garlic, 1 teaspoon of finely ground ginger, 2 spoons of finely ground galingale, $1 / 4$ kilogram of finely ground turmeric, 2 lemon grasses, 5 lime (Purut) leaves, 3 bay leaves, 1 turmeric leaf, 1 teaspoon of salt, and 1 spoon of finely ground coriander.

The process of cooking rendang lokan is the same as rendang with meat, using hand and wood for cooking not by gas or electrical stove. This is because they think the taste will be different if the cooking uses gas/electrical stove. The process takes quite long time, around 6 to $8 \mathrm{~h}$ in order to get the ideal texture and color-dark brown-with oil in it (Fig. 5).

The process of cooking rendang is done in a traditional way, including the materials, which are rich of local spices, gives a certain taste and not less than rendang with meat. The fresh oyster as the seafood mixed with tasteful coconut milk and fresh spices creates the uniqueness of Minangkabau culinary. Thus, it is a kind of rendang which becomes favorite culinary for people in West Sumatra since it contains good nutrition and its price is cheap.

The uniqueness of the rendang lokan is on its ingredients and spices. The vegetables used as the ingredients are fern (pakis) and cassava leaves that are never used for rendang with meat. Fern (pakis) is a kind of wild plantation that grows up along the bank of rivers, mangrove area, while cassava grows around 


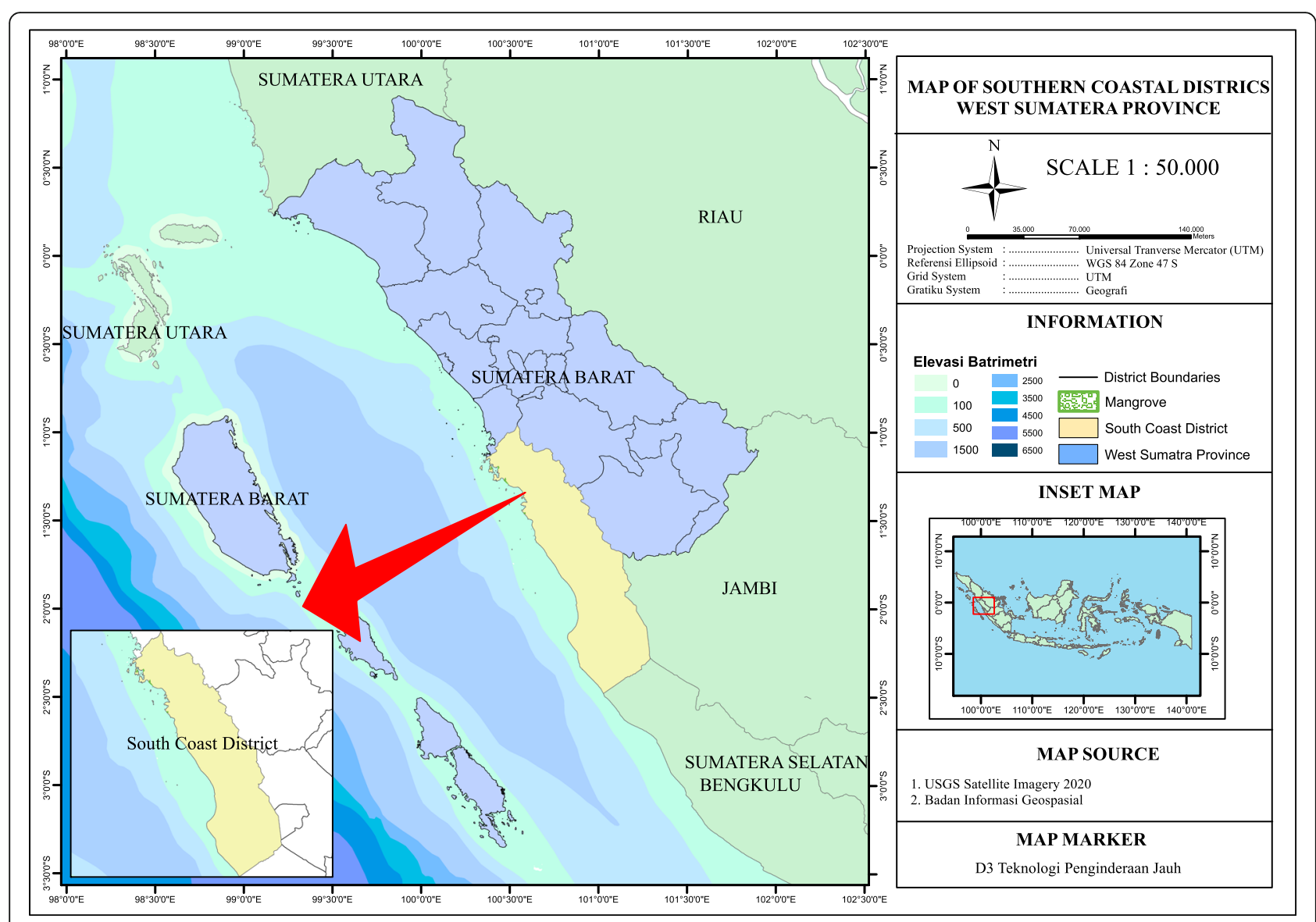

Fig. 2 Maps of Mangrove area and Pesisir Selatan Regency of West Sumatra Province

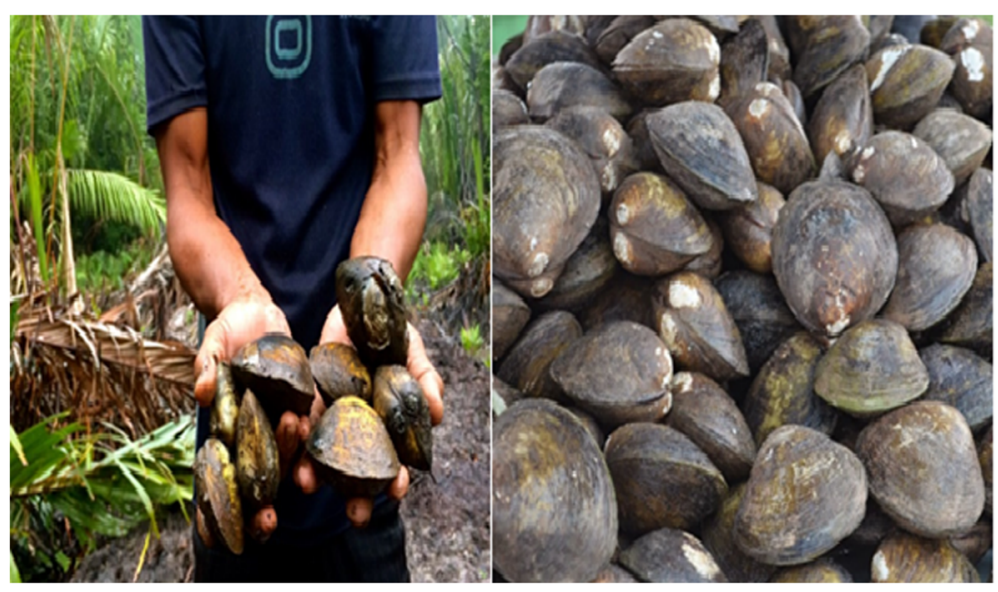

Fig. 3 Oyster as the resource of mangrove area 


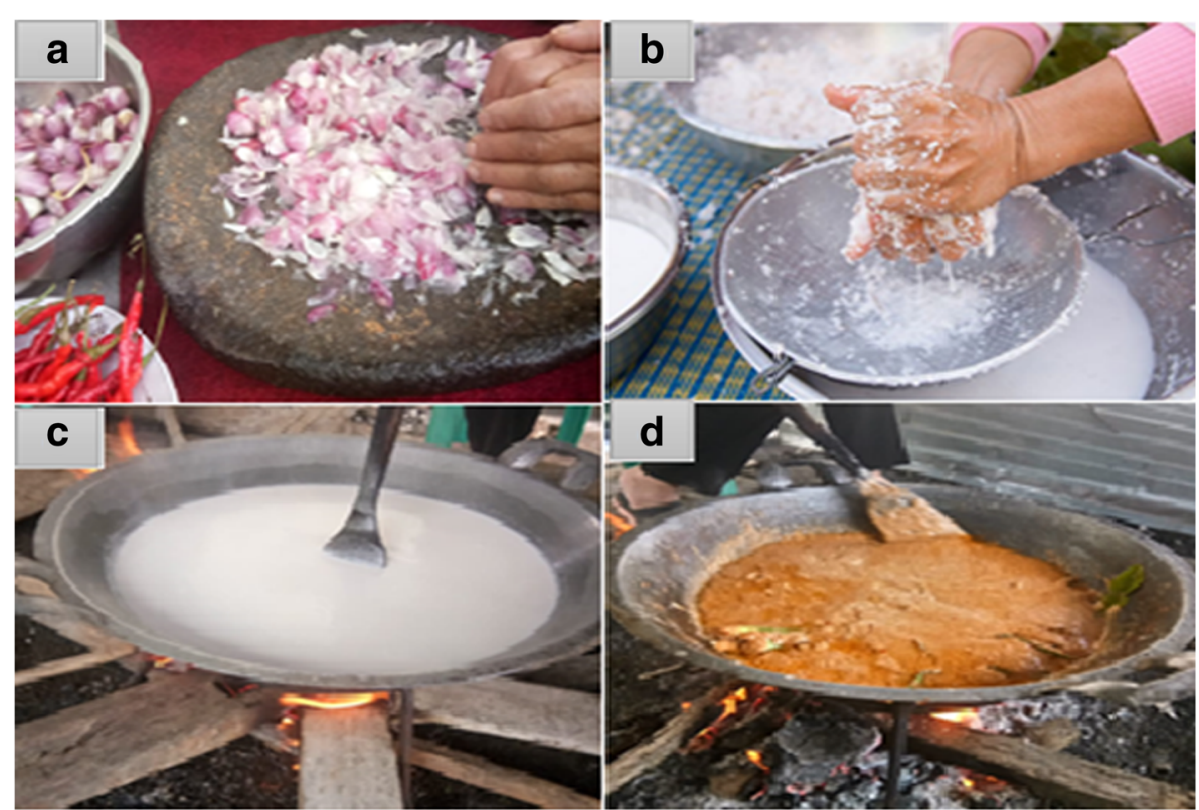

Fig. 4 The process of rendang lokan in a traditional way. a To grind the spicy by stone, $\mathbf{b}$ to squeeze the milk out of coconut, $\mathbf{c}$ the coconut milk is cooking, $\mathbf{d}$ then the ingredients is poured into the coconut milk while it is cooked by using wood

their houses and its tuber (singkong) is a substitute for rice. The combination of these vegetables makes rendang more delicious and both of them have high iron contents (Fig. 6).

The variation of rendang lokan also shows the community wisdom in utilizing the resources that exists around them. Rendang is not necessary with meat, but it can be with other animals' protein and vegetables. It means rendang has expansion of meaning not only in its materials and ingredients but also in the way it is cooked.

\section{Rendang lokan: marine tourism icon of West Sumatra}

The uniqueness taste of rendang lokan makes it acceptable in West Sumatra culinary market. At the beginning, it is only as a food for family for coastal community which serves for the celebration days and religious day. Today, it is one of the tribe's food which is demanded by tourists who came to West $\mathrm{Su}$ matra. The high demand makes it easy to find in any food store especially for traditional food of Minangkabau. Besides, along with the development of tourism in Pesisir Selatan Regency, rendang lokan has been popular in foreign countries.

Today, it is easy to find rendang lokan from coastal area in any food stores and restaurants. It is common for the restaurants to serve it as their main menu, especially on the marine tourism resort. It also can be found in the traditional food center of Minangkabau which are

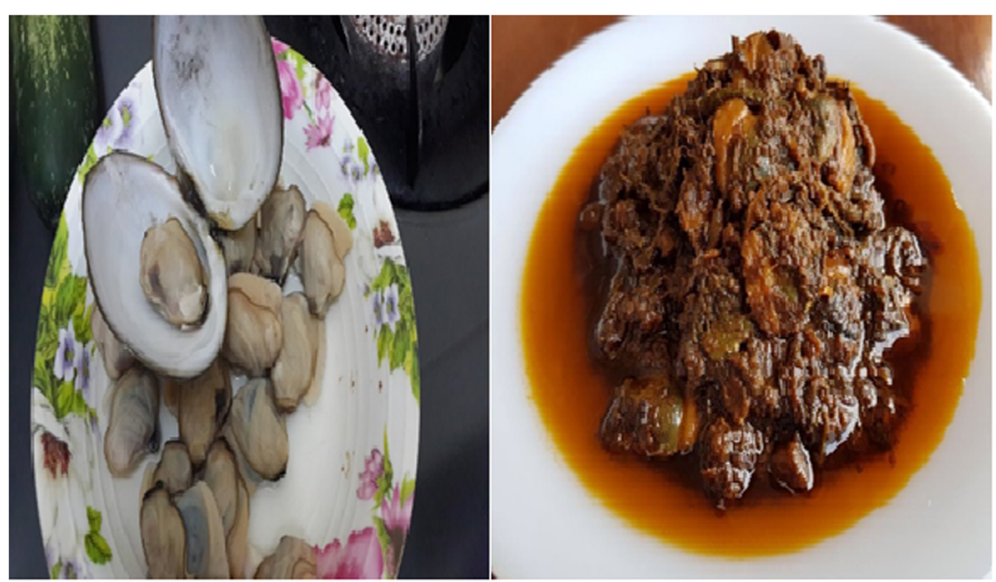

Fig. 5 a Lokan (fresh oyster) without skin. b Rendang lokan 


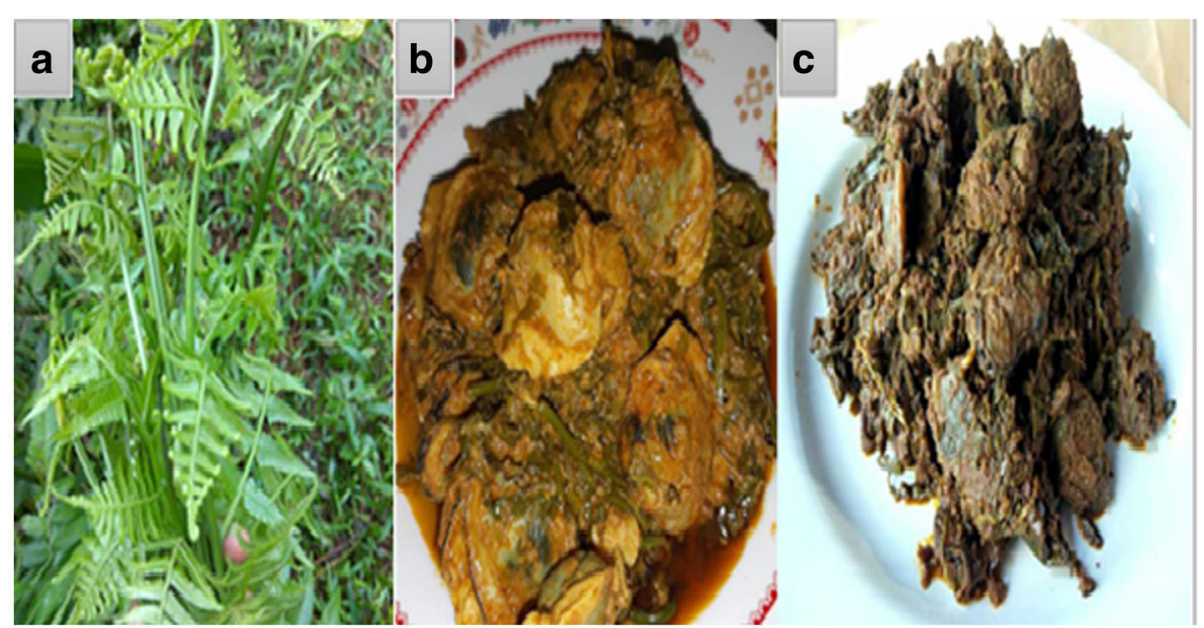

Fig. 6 a A kind of fern (pakis), b curry lokan pakis (kalio lokan pakis), c Rendang lokan with fern (rendang lokan pakis)

put beside rendang with meat of cow or buffalo on the shelf (Fig. 7).

Rendang lokan becomes more popular since the Mandeh Islands integrated tourism is developed in Pesisir Selatan Regency and now it is an icon of marine tourism in West Sumatra, Indonesia. This resort has become more crowded since 2016. The area consists of 4 main villages where mostly of the people are fishermen including a searcher of oyster when the fish season is less. The people who search the oysters are commonly women to fulfil their daily need if the fish are less. The area was isolated before. The access to the remote village only was reached by boat or small ship when the weather was good. Although the islands are called The Hidden Paradise for its beautiful scenery, not many people come to visit the place because of the lack of transportation. On 10 October 2015, the President of Indonesia, Joko Widodo, calls it a Raja Ampat (the same as the beautiful place in Papua Island) on the west of Indonesia. In 2018, the $42-\mathrm{km}$ road which connected the four villages was completed. Thus, the area becomes one of the strategic tourist resorts in Indonesia [25].

Since the area becomes more popular as the tourist resort on the west of Sumatra, the specific food of the tribes on Mandeh area also sold out. One of them is rendang lokan as their cultural identity as well as their

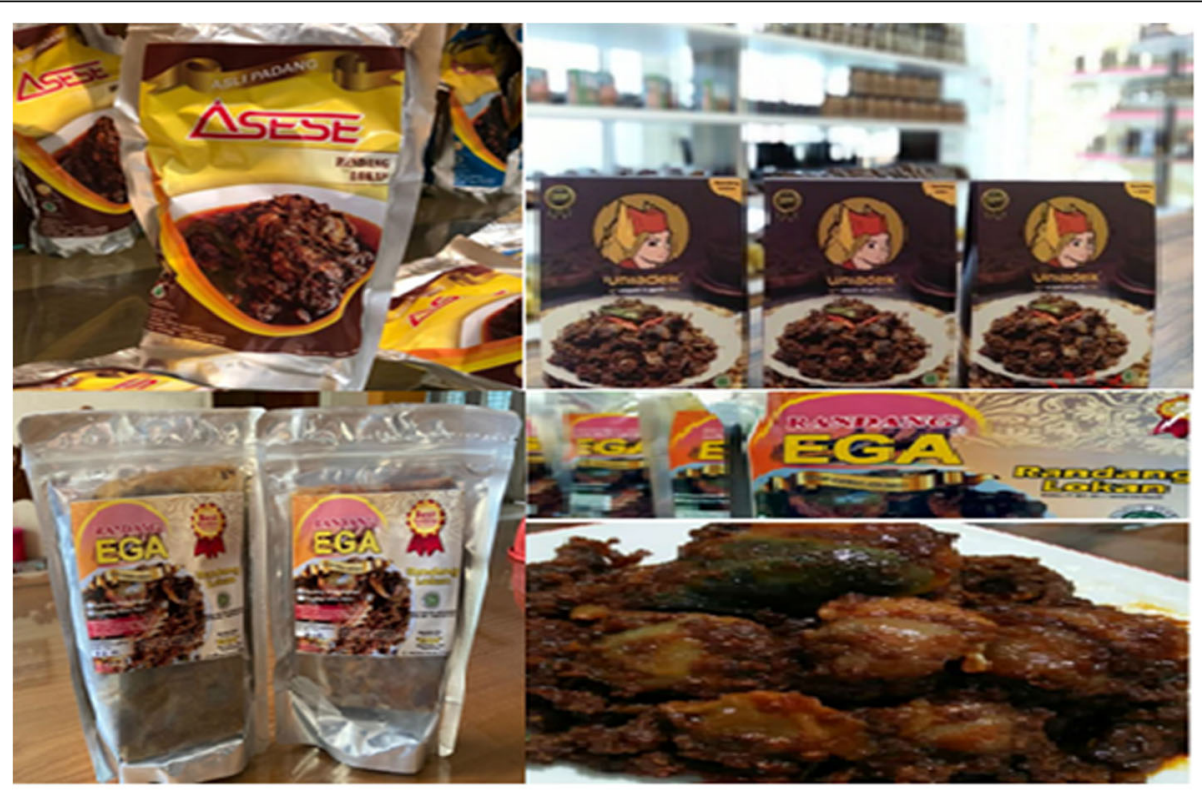

Fig. 7 The package of rendang lokan in a food store 
pride. Mandeh is also known as a mangrove area. The place causes people livelihoods on the mangrove area that is to search the oysters for selling or their own food. The resource of their area is developed to specific culinary of Mandeh integrated tourism which is sold in many restaurants to be enjoyed by visitor.

Referring to the high demands of rendang lokan and the increase of local society economy, the government is intent on giving several trainings how to process and pack it so that it can be a kind of souvenir. It is just a local food before, but now it is one of the favorite commodities for tourists at the market. It contests to the rendang with meat at global market. Rendang lokan currently becomes one of the mainstays of typical culinary tourism in Mandeh Islands.

The results of the interviews with rendang lokan entrepreneurs around Mandeh Islands reveal that the tourists show their positive responses to the tastes of rendang lokan because some of them continue ordering rendang lokan online after their return to their home country. Almost every day the rendang lokan entrepreneurs manage online requests for rendang lokan from foreign countries. The highest demand is from Japan, Malaysia, Singapore, European countries, and Australia. This proves that rendang lokan is a traditional food of the Minangkabau coastal community which is already popular in foreign countries, as is the popularity of beef rendang.

The popularity of rendang lokan as a typical traditional food in West Sumatra is in line with the development of marine tourism in Pesisir Selatan Regency. Rendang lokan does not only become a part of local wisdom of Minangkabau people living in coastal areas of West Sumatra, but it also becomes a source of their income that increases along with the development of tourism sector. In this context, tourism and local traditional culinary are two sectors that influence each other. Tourism requires local traditional culinary as an enhancer for tourism attraction, while traditional food also requires tourism activities as a promotional medium in order to be accepted and able to compete in national and global markets $[26,27]$.

\section{Rendang lokan: cultural identity and adaptation of Minangkabau people to the environmental condition in West Sumatra}

Rendang, one of the manifestations of Minangkabau people's cultural identity, is a marker that distinguishes them from other tribes. It is a cultural heritage and a pride of Minangkabau people, passed down from generation to generation. The globalization today is the challenge since the mobility of commodities and people run smoothly so that the fast food and many kinds of food from different culture exist with varieties of taste and the price are cheap. The young generation tend to choose fast food rather than rendang for it is practice and does not take times to cook like rendang with complicated process. As a result, Minangkabau people are forced to have creativity to keep the heritage food, so that they can sustain the cultural identity to each generation. The innovation for processing local food to be in demand by others is crucial [28], so that the traditional food is able to compete to fast food and the modern ones.

The variation of rendang is an evidence to show the high creativity and innovation of people to sustain their cultural identity. This is also to prove that cultural identity has modification in line with the developing of people creativity as the creator and user [29]. Besides, the choice of oyster processing to be rendang is the way of coastal society in using the resource of nature around them, adapting to the local environment as well as their economic conditions. These become the marker of creativity and innovation in facing the nature including to survive [30, 31].

Alam Takambang Jadi Guru (learning from the nature) is the philosophy of Minangkabau people in interacting with nature. The availability of oyster which is easier to get and costs cheaper triggers the local people to use it as the main ingredient for rendang. The custom runs well, and it keeps as the main food even though the main material is not the same, as the meat is substituted by oyster. Rendang lokan is the main food to be served to the head of clan in the coastal district's customs, not rendang with meat as in other areas in West Sumatra.

Referring to the explanation above, it shows how Minangkabau people are so flexible to handle the problems and make modification based on their daily need in order to save their live. Rendang lokan represents the character of Minangkabau people who are creative and adaptive to their local environmental conditions and hold fast to their cultural identity (Table 1).

This is in line with Stuart Hall and Crish Barker who say that cultural identity is the construction [32]. Thus, the cultural identity is flexible not permanent. The construction is a continually process through the space and time [33]. It is supported by Homi K Bhabha that cultural identity is not inheritance but the entity which continuously negotiate and adjust to the situation [34]. In other words, cultural identity can have adaptation based on the need and demand of the society [35].

\section{Conclusion}

Rendang lokan is one of specific culinary in a coastal area of west Sumatra that has oyster, a kind of Geloina Erosa as its material, which exists in mangrove area called Lokan. The findings indicate that rendang lokan 
Table 1 Recapitulation of the main research findings

\begin{tabular}{|c|c|}
\hline $\begin{array}{l}\text { Representation of rendang lokan for } \\
\text { Minangkabau community }\end{array}$ & Research findings \\
\hline Rendang Lokan as a form of adaptation & $\begin{array}{l}\text { Rendang lokan is created because of the adaptation of the people living around the coastal areas of } \\
\text { West Sumatra to the local natural resources and their economic conditions. The high price of beef/ } \\
\text { buffalo meat as the main ingredient of rendang challenges them to innovate and be creative in } \\
\text { modifying rendang. Rendang, which used to be made from beef or buffalo meat, is modified by } \\
\text { using shellfish of Geloina Erosa type that lives in mangrove areas as the main ingredient, which } \\
\text { Minangkabau people call Lokan. Rendang lokan is a form of adaptation of the Minangkabau people } \\
\text { to their living conditions, so that they can still enjoy rendang at a more affordable price and with } \\
\text { high nutrition, but without losing the distinctive taste of local ethnic food as the pride of the } \\
\text { Minangkabau community's ancestors. }\end{array}$ \\
\hline Rendang lokan and cultural identity & $\begin{array}{l}\text { Rendang, one of the manifestations of Minangkabau people's cultural identity, is a marker that } \\
\text { distinguishes them from other tribes. It is a cultural heritage that becomes a pride of Minangkabau } \\
\text { people, passed down from generation to generation for its sustainable existence. Variations of } \\
\text { rendang, such as rendang lokan, are evidence of the high creativity and innovation of Minangkabau } \\
\text { people who live in coastal areas in order to maintain their cultural identity which is manifested in the } \\
\text { form of local ethnic food. Moreover, this also proves that cultural identity can be modified along with } \\
\text { the development of human creativity as a culture creator and user. }\end{array}$ \\
\hline Rendang lokan and tourism & $\begin{array}{l}\text { Rendang lokan, which used to be a culinary tradition of people living in coastal areas usually served } \\
\text { as a special dish at family celebrations and holy day celebrations, has now become a market } \\
\text { commodity that is in high demand by tourists. The demand is quite high, making rendang lokan } \\
\text { now easy to find in various shops selling traditional Minangkabau food souvenirs. Lokan rendang, } \\
\text { which used to be a local food, has now become a market commodity favoured by tourists, just like } \\
\text { beef rendang which has been well-known in the global market. In this regard, rendang lokan as the } \\
\text { cultural identity of people living in the coastal areas of West Sumatra, which was previously created } \\
\text { due to the adaptation process, has now become one of the sources of livelihood for the local } \\
\text { community. }\end{array}$ \\
\hline
\end{tabular}

Source: Authors

is the representative of the characteristics of Minangkabau people who have the ability to adapt themselves to their local environmental conditions in order to maintain their cultural identity. This is created by people who live in coastal areas in West Sumatra in order to adjust to the local environment and their economic conditions. Nowadays, rendang, which used to be simply the local food and was served only during celebration days, becomes popular in the market and it is easy to find in restaurants and traditional Minangkabau food shops. Besides, it is now a commodity which is demanded by tourists, as is rendang with beef or buffalo meat. It has been able to compete in a global market. Rendang lokan is getting its royalty soon as it has been internationally branded as a specific culinary of Minangkabau people living in the coastal areas of West Sumatra, especially in Pesisir Selatan Regency. Moreover, it has become an icon of international tourism located in Pesisir Selatan Regency.

Rendang lokan, which is one of many other kinds of rendang found in West Sumatra, is the focus and limitation of this article. There are many other kinds of rendang found in West Sumatra reflecting typical characteristics of each region with their unique historical background that can be studied by other researchers. The study on rendang lokan has implications for the development of knowledge in understanding the meaning and social functions of traditional foods that are useful for preserving Minangkabau traditional foods in the midst of global competition. The excellence of this article is that it provides comprehensive knowledge about traditional food which does not only reflect a cultural identity and fulfilment of the local people's life needs but also shows their ability to adapt themselves to the local natural resources.

\section{Acknowledgements}

The author wishes to thank interviewees for their cooperation and valuable information. Thank you so much to Dr. Kurnia Ningsih, M.A., Dr. Rusdi Noor Rosa, S.S., M. Hum., and Prof. Dr. Hasanuddin WS, M. Hum, who have helped the authors in the process of writing this article in terms of language issues and proofreading.

\section{Authors' contributions}

SF devised the main conceptual ideas, data collection, and data analysis. DS reviewed the literature and wrote this manuscript. W and RZ performed manuscript drafting and incorporating revisions. All authors read and approved the final manuscript.

\section{Authors' information}

Siti Fatimah is a lecturer (PhD) in the Department of History, Faculty of Social Sciences, Universitas Negeri Padang, West Sumatra. Indonesia. Delmira Syafrini is a lecturer (PhD) in the Department of Sociology, Universitas Negeri Padang, West Sumatra, Indonesia. Wasino is a lecturer (Professor) in the Department of History, Faculty of Social Sciences, Universitas Negeri Semarang, Central Java, Indonesia. Rahadian Zainul is a lecturer (PhD) in the Department of Chemistry, Faculty of Mathematics and Natural Sciences, Universitas Negeri Padang, West Sumatra, Indonesia.

\section{Funding}

This study did not receive the support of certain costs from the funding agency in the public, commercial, or non-profit sector. 


\section{Availability of data and materials}

We do not wish to share our data due to some confidential statement from some information which cannot be shared in public.

\section{Declarations}

\section{Competing interests}

The authors declare that they have competing interests.

\section{Author details}

'Department of History, Faculty of Social Sciences, Universitas Negeri Padang, West Sumatra, Indonesia. ${ }^{2}$ Department of Sociology, Faculty of Social Sciences, Universitas Negeri Padang, West Sumatra, Indonesia. ${ }^{3}$ Department of History, Faculty of Social Sciences, Universitas Negeri Semarang, Central Java, Indonesia. ${ }^{4}$ Department of Chemistry, Faculty of Mathematics and Natural Sciences, Universitas Negeri Padang, West Sumatra, Indonesia.

Received: 4 May 2021 Accepted: 11 July 2021

Published online: 28 July 2021

\section{References}

1. S. Utami, Kuliner Sebagai Identitas Budaya: Perspektif Komunikasi Lintas Budaya, J. Strateg. Commun., vol. 8, no. 2, pp. 36-44, 2018, [Online]. Available: http://journal.univpancasila.ac.id/index.php/coverage/article/ download/588/332

2. Almerico GM. Food and identity: food studies, cultural, and personal identity Gina M. Almerico, Ph. D. The University of Tampa. J Int Bus Cult Stud. 2014; $8(1): 1-8$.

3. Cherry E, Ellis C, DeSoucey M. Food for thought, thought for food: Consumption, Identity, and Ethnography. J Contemp Ethnogr. 2011;40(2): 231-58. https://doi.org/10.1177/0891241610379122.

4. BPS, Mengulik Data Suku di Indonesia, Jakarta, 2015. [Online]. Available: https://www.bps.go.id/news/2015/11/18/127/mengulik-data-suku-diindonesia.html.

5. Pitoyo AJ, Triwahyudi H. Dinamika Perkembangan Etnis di Indonesia Dalam Konteks Persatuan Negara. Populasi. 2017;25(1):64-81.

6. Cheung T. Your pick: World's 50 best foods. CNN. 2017. https://edition.cnn. com/travel/article/world-best-foods-readerschoice/index.html. Accessed 15 Mar 2021.

7. Rini F, Azima K. Sayuti, and Novelina, The evaluation of nutritional value of rendang Minangkabau. Agric Agric Sci Procedia. 2016;9:335-41. https://doi. org/10.1016/j.aaspro.2016.02.146.

8. Galimpin-Johan SMC, Rahman RA, Jamilah B, Man YBC, Rusul G. Pasteurization, development and storage of sous vide rendang (spicy beef stew). J Food. 2007;18(6):251-63. https://doi.org/10.1111/j.1745-4506.2007. 00071.x.

9. Nurmufida $M$, Wangrimen $\mathrm{GH}$, Reinalta $\mathrm{R}$, Leonardi $\mathrm{K}$. Rendang: the treasure of Minangkabau. J Ethn Foods. 2017;4(4):232-5. https://doi.org/10.1016/j.jef.2 017.10.005.

10. Rahman F. Tracing the origins of rendang and its development. J Ethn Food. 2020;7(28):1-11. https://doi.org/10.1186/s42779-020-00065-1.

11. Fresco LO. Challenges for food system adaptation today and tomorrow. Environ Sci Pol. 2009;12(4):378-85. https://doi.org/10.1016/j.envsci.2008.11. 001.

12. Durazzo A, et al. Nutritional composition and dietary intake of composite dishes traditionally consumed in Italy. J Food Compos Anal. 2019;77:115-24. https://doi.org/10.1016/j.jfca.2019.01.007.

13. A. K. Nadra, E. Nora, P. Studi, U. Perjalanan, J. A. Niaga, and P. Negeri, Rendang lokan as a culinary tourism attraction in Pesisir Selatan, J Bus Hosp Tour, vol. 6, no. 2, pp. 401-407, 2020, [Online]. Available: https://www.jbhost. org/jbhost/index.php/jbhost/article/view/259.

14. Kimura M. Food, national identity and nationalism: from everyday to global politics. Ethn Racial Stud. 2016;39(13):2450-2. https://doi.org/10.1080/0141 9870.2016.1161813.

15. Hall S. Cultural identity and diaspora. In: Rutherford J, editor. Identity: Community, Culture, Difference. London: Lawrence \& Wishart; 1990. p. 22238.

16. P. Boski, K. Strus, and E. Tlaga, Cultural identity, existential anxiety and traditionalism, in Ongoing themes in psychology and culture: Proceedings from the 16th International Congress of the International Association for Cross-
Cultural Psychology, 2004, pp. 457-474, [Online]. Available: https://schola rworks.gvsu.edu/cgi/viewcontent.cgi?article $=1263 \&$ context=iaccp_papers

17. Misztal BA. Durkheim on collective memory introduction : the Durkheimian tradition. J Class Sociol. 2003;3(2):123-43. https://doi.org/10.1177/14 $68795 \times 030032002$

18. Lipoeto NI, Agus Z, Oenzil F, Masrul M, Wattanapenpaiboon N, Wahlqvist ML. Contemporary minangkabau food culture in West Sumatra, Indonesia. Asia Pac J Clin Nutr. 2001;10(1):10-6. https://doi.org/10.1046/j.1440-6047.2 001.00201.x

19. Denzin NK, Lincoln YS. Handbook of Qualitaive Research. Yogyakarta: Pustaka Pelajar; 2009

20. Yadegari Z. The study of the capabilities of oral methods of intercultural communication in transmission and preservation of concept in cultural heritage. Bagh-e Nazar. 2021;17(92):113-24. https://doi.org/10.22034/bagh.2 020.188518 .4145 .

21. Miles MB, Huberman AM. Qualitative data analysis. London: SAGE Publication; 1994.

22. Bruhn KL. Community and the Rantau: West Sumatran artists in Indonesia's art world. Southeast Now Dir Contemp Mod Art Asia. 2018;2(2):119-42. https://doi.org/10.1353/sen.2018.0004.

23. Naim M. Merantau: causes and effects of Minangkabau voluntary migration: ISEAS PUBLISHING; 1971. https://doi.org/10.1355/9789814380164.

24. N. T. Agustini, D. G. Bengen, and T. Prartono, Asosiasi Kerang Lokan, Geloina Erosa Solander 1786 dan Mangrove di Kawasan Pesisir Kahyapu Pulau Enggano Provinsi Bengkulu, J Ilmu dan Tekonologi Kelaut Trop, vol. 8, no. 2, pp. 613-624, 2016, [Online]. Available: https://media.neliti.com/media/ publications/100596-ID-association-of-lokan-shell-geloina-erosa.pdf.

25. S. Fatimah, D. Ramadhan, and R. Susanti, Local wisdom in supporting sustainable tourism in the Mandeh Region, Pesisir Selatan, West Sumatra, in 3rd International Conference on Social and Political Development (ICOSOP 3 2019) - Social Engineering Governance for the People, Technology and Infrastructure in Revolution Industry, 2020, pp. 341-346, doi: 10.5220/ 0010021203410346.

26. Bessiere J, Tibere L. Traditional food and tourism: French tourist experience and food heritage in rural spaces. J Sci Food Agric. 2013;93(14):3420-5. https://doi.org/10.1002/jsfa.6284.

27. Cohen E, Avieli N. Food in tourism - attraction and impediment. Ann Tour Res. 2004;31(4):755-78. https://doi.org/10.1016/j.annals.2004.02.003.

28. Harrington RJ, Ottenbacher MC. Managing the culinary innovation process: The case of new product development. J Culin Sci Technol. 2013;11(1):4-18. https://doi.org/10.1080/15428052.2012.754724.

29. Lauer HR. Perspectives on social change. Boston: Allyn and Bacon; 1993.

30. V. Richard, J. Lebeau, F. Becker, and E. R. Inglis, Do more creative people adapt better? An investigation into the association between creativity and adaptation, Psychol Sport Exerc, vol. 38, no. September, pp. 80-89, 2018, doi: https://doi.org/10.1016/j.psychsport.2018.06.001.

31. Cohen LM. Adaptation and creativity in cultural context. Rev Psicol. 2012; 30(1):3-18. https://doi.org/10.18800/psico.201201.001.

32. Barker C. Cultural studies, theory and practice. London: SAGE Publication; 2000.

33. Jacobson J, Hall S, Du Gay P. Questions of cultural identity. Br J Sociol. 1997; 48(1):153. https://doi.org/10.2307/591920.

34. Gandhi L. Postcolonial theory: a critical introduction. Australia: Allen \& Unwin; 1998.

35. Syafrini D, Fadhil Nurdin M, Sugandi YS, Miko A. The impact of multiethnic cultural tourism in an Indonesian former mining city. Tour Recreat Res. 2020; 45(4):511-25. https://doi.org/10.1080/02508281.2020.1757208.

\section{Publisher's Note}

Springer Nature remains neutral with regard to jurisdictional claims in published maps and institutional affiliations. 